\title{
Moscow to be a New Offshore Centre of the Yuan
}

\author{
Doctor of Economics, \\ Mikhail Zharikov \\ Professor of the World Economy and World Finance Department, \\ Financial University, Moscow, Russia \\ michaelzharikoff@gmail.com \\ http://orcid.org/0000-0002-2162-5056
}

\begin{abstract}
In the paper, the author has formulated and proven the hypothesis according to which among the international financial centres of the BRICS Moscow is the most promising one in terms of becoming a new yuan's offshore centre since there is a working niche for trades in currency pair rouble/yuan. And also, there are commercial banks in Moscow that take deposits in yuan both from individuals and legal entities. According to the conducted research, the author demonstrated the opportunities and optimal ways to use an advantage which presupposes the creation of an investor-friendly environment for Brazil, India and South Africa to trade in currency pair rouble/yuan at the Moscow Exchange. It can be possible in case of direct settlements in yuan in case of direct transactions between the mentioned countries and China both when exporting and importing.

Keywords: the BRICS; rouble internationalisation; yuan's offshore centre in Moscow; the international monetary system; Eurasian Economic Union; Eurasian monetary integration; yuan currency vehicles; yuan contractual exchange rates

JEL Classification: F37
\end{abstract}

...And so there will be a city-garden here... Vladimir Mayakovsky

The major conclusions of this article come out of the hypothesis that direct settlements between Brazil, Russia, India and South Africa, on the one hand, and China on the other will lead to the creation of a new offshore centre of the yuan in Moscow by means of circulating currency vehicles traded at the Moscow Exchange. The author hereby proves on the basis of calculating the values of Brazilian, Russian, Indian and South African exports to China and imports from China that if more favourable conditions to buy and sell the yuan at the Moscow Exchange are created in contrast to the terms offered by the central banks, the authorized commercial banks and the Chinese Foreign Exchange Trading System (CFETS) as well as in comparison with the terms of trading in yuans by means of swap agreements between the BRICS' central banks, then the non-Chinese BRICS exporters and importers will be more active in purchasing the yuandenominated currency vehicles at the Moscow Exchange to transact with Chinese counterparts, so that not only the yuan will gradually become a more internationalised currency but also the rouble, and Moscow will become a new yuan's offshore centre and later an international financial centre.

One of the prerequisites of organising direct settlements between the BRICS in national currencies in the increasing share of the BRICS (without Russia) in the Russian foreign trade. As can be seen in Table 1 this is revealed most notably in the bilateral foreign trade between Russia and China. For example, in 2015 China accounted for 7.7 per cent of Russian exports and 19.3 per cent of its imports. The dynamics of Russian and Chinese trade is quite positive.

The comparative analysis of the rest of the world and the BRICS in the Russian foreign trade shows the trend which indicates that the share of the former in the Russian exports and imports 
gradually decreases, whereas the share of the later continually increases (Table 2).

For the BRICS (without Russia) Russia remains a foreign trade partner of less significance compared to the other countries. Russia has only a 2 per cent share in its exports and imports (Table 3).

To a certain extent, the mechanism described here operates like a financial network which is formed by the international swap agreements as well as financial funds such as the BRICS Development Bank. However, the swap agreements which, for instance, China concludes with various countries of the world require the exchange of liquid flows between them in case of financial difficulties, force-major conditions, a necessity to service the current-account deficits, and finance the budget deficits or stabilise the national currency's exchange rate. Swap agreements are usually concluded for vast amounts of money, and therefore they exclude the possibility of small, medium and perhaps some big enterprises as well as participating in them. Among commercial enterprises, such a contract can be concluded only by the multinationals with annual total revenue exceeding 100 billion dollars. Russian multinationals of the sort include only Gazprom and Lukoil. As a whole, the intergovernmental swap agreements are not really applicable for conducting foreign trade deals, especially between private corporations.

As can be seen in the conditions of concluding the swap agreements to facilitate the foreign trade between Brazil, Russia, India and South Africa, on the one hand, and China on the other, other instruments are needed which could have extended the opportunities of these countries' business entities to use the national currencies (Schindler, 2009). In the world practice, such opportunities are usually gained through operating foreign exchange markets and offshore centres where besides fully convertible hard currencies the BRICS' currencies can be traded (Kaufman, 2001).

Among the emerging international financial centres of the BRICS such as Sao Paulo, Mumbai or Johannesburg, the most prospective one in terms of a future yuan's offshore centre is Moscow. It is due to the following reasons:

1) Moscow Exchange is the only foreign exchange market among the BRICS where there are trades done in currency pair rouble/yuan;
2) The trade turnover between Russia and China is one of the largest in volume compared to bilateral exports and imports balance of the rest of the BRICS;

3) Russia and China have a common border, cooperate in customs control and create the mechanisms of cross-border flows of goods and services and financial capital;

4) Among the BRICS Russia and China have long-term expertise in organising direct settlements in rouble and yuan.

Since China is a more important trading partner for Russia, Brazil, India and South Africa that the latter for the former, it is quite sensible to conduct the settlements between them in yuan under the conditions of keeping monetary sovereignty and their currencies. Using its privileged positions, the Moscow Exchange need to create the environment and prerequisites of buying and selling yuan by Brazil, India and South Africa (Yu, 2014). Buying and selling yuan at the Moscow Exchange can be done by the following means:

1) The most beneficial alternative for Russia in making such trade is buying roubles for dollars and yuan for roubles. The advantage of this scheme is that by trading yuan at the Moscow Exchange through currency pair rouble/yuan, there will be additional liquid assets in hard currency (the dollar) coming into Russia.

2) A second alternative would be exchanging reals, rupees and rands for roubles at the Bank of Russia's exchange rate and purchasing yuan for the acquired roubles at the Moscow Exchange. In this case, there will be an accumulation of international reserves in reals, rupees and rands in Russia. The effect of such transactions for the Russian economy is going to be the diversification of foreign exchange reserves and an opportunity for the Russian importers to settle the deals of product delivery from Brazil, India and South Africa in the national currencies.

Foreign direct trade deal settlements between China, on the one hand, and Brazil, Russia, India and South Africa, on the other, can be done as follows:

Through central bank and commercial banks intermediation: this way is costly because in case of direct settlements when importers buy Chinese products they need to purchase the foreign currency (dollars) for the national currencies (reals, roubles, rupees and rands), then they 
should deposit the acquired dollars on special transaction accounts of the Chinese authorised banks, exchange them for yuan, and only after that they may settle with the deliverers of the Chinese products (Goldberg, Cédric, 2008). The benefits of such an exchange will mostly fall on the central banks and authorised commercial banks. For the importers of the BRICS (without China), this will result in high transaction costs, which will prevent the mutual trade development.

Through the intermediation of a foreign exchange market in case of its having a respective niche to trade in yuans: in this particular situation yuans could be directly purchased for the national currencies (reals, roubles, rupees and rands), and despite the fact that an exchange rate of these currencies to yuan in the foreign exchange market may sometimes seem less beneficial in comparison to the official exchange rates of those currencies at the national central banks (i.e. to purchase one yuan in the foreign exchange market you would usually require more reals, roubles, rupees and rands than for the same operation at central bank's rates), the costs of transacting through the central bank usually exceed the benefits. This happens due to the fact that to purchase the yuan at the central bank's exchange rate is impossible after all, since at first Brazilian, Russian, Indian and South African importers of Chinese products will have to open a special account with one of the authorised commercial banks which are allowed by the Chinese government to take deposits in yuan, and only then they will eventually be able to buy yuan at an exchange rate of those banks (Avdokušin, Kovalenko, 2012). On the whole, it means that the importers of Chinese products get no profit when purchasing yuan at the central bank and commercial banks.

Through the intermediation of the currency offshore centres. A yuan offshore centre usually coincides geographically with an international financial centre where there are the necessary conditions to deal in that currency. The trading procedure at the offshore centre and that at the foreign exchange are distinct from each other, first of all, because at the latter there must be a two currencies' pair (e.g. rouble/yuan) in which the trading is done within one or several lots. In contrast to the foreign exchange market, the currency pair at an offshore centre is not a ne- cessity, and a person has an opportunity to buy and sell the currency in exchange for any other convertible one with no limits at all, which are usually present when dealing in currency pairs. Consequently, for Moscow to become a yuan offshore centre, it needs to change the trading procedures from simple currency pair deals over to deals with any convertible currency on choice (Binder, 2013). Also, in such an offshore centre there must be a sufficient number of commercial banks which take deposits in yuan and a specially advanced infrastructure constituted of institutions such as insurance companies, consulting agencies, auditing firms, accounting offices, legal advisories, hedge funds, etc. which provide specialised services to assist in yuan trading or opening yuan deposits (Butorina, 2011).

Taking this into consideration, the prerequisites of creating an offshore centre of yuan in Moscow are as follows:

1) There is a niche to trade in currency pair rouble/yuan;

2) There is an existing portfolio of foreign exchange vehicles to trade in currency pair rouble/yuan;

3) There are some commercial banks taking deposits in yuan from both the individuals and legal entities, e.g. VTB Bank, Eastern Express, etc.

The existing niche to trade in the currency pair rouble/yuan in the Chinese Foreign Exchange Trading System in Shanghai, which creates the conditions for wider international use of the rouble in cross-border deals and which will affect this currency pair trading at the Moscow Exchange. Trading in the currency pair yuan/ rouble in Shanghai may also influence on the same currency pair trading in Moscow in case of Chinese importers deciding to purchase Russian products for roubles. It will certainly lead to increasing demand for roubles, and the foreign exchange market in Shanghai will need extra liquid assets expressed in roubles. Increasing demand for roubles will become a factor helping strengthen its exchange rate towards the leading currencies of the world (Lane, Milesi-Ferretti, 2011). In contrast, a more expensive rouble would be a factor which may decrease the competitiveness of Russian exports to China. Then the Bank of Russia will have to inject additional liquidity into the interbank market which may result in rouble's exchange rates toward yuan at the 
Moscow Exchange, which would consequently cause changes in the value of the contracts to buy and sell yuan. However, at the same time, a more expensive rouble at the Moscow Exchange is good for the Russian importers of the Chinese products because it will take fewer roubles to buy a yuan.

To prove the hypothesis that in case of covering Chinese imports to Brazil, Russia, India and South Africa and the latter's exports back to China in yuan with the Moscow Exchange's intermediation, Moscow may become a new yuan offshore centre, it is necessary to conduct the analysis of the mutual trade directions between these trade partners taking in account the possibility of using currency vehicles to buy and sell yuan in the foreign exchange markets in Moscow and Shanghai (Kasekende, Brixova, Ndikumana, 2010). These trade directions depict flows of goods and services from one BRICS nation to the other at a value expressed in dollars and at a value converted into the national currencies to compare the costs and benefits connected with the transition to direct settlements (Kadayan, 2014).

The initial data to calculate the gap between the imports/exports value expressed at different yuan's exchange rates show that the rouble's exchange rate fluctuations have an enormous significance in direct settlements. For example, in 2012 the rouble to yuan exchange rate amounted to more than 20 roubles a yuan in Bank of China (a bank authorised by the People's Bank of China), whereas it cost approximately 5 roubles a yuan in the Bank of Russia. One of the reasons of such an exchange rate gap was the willingness of China's monetary authorities to concentrate the trading in currency pair rouble/yuan in the foreign exchange market in Shanghai. There there were more convenient terms for such deals as well as it wanted to limit speculative attacks in deals with this currency pair and increase the share of rouble and yuan's use in the mutual cross-border trade deals. By 2015 the rouble to yuan exchange rates narrowed down to about 11 roubles a yuan at the Bank of China and about 9 roubles a yuan at the Bank of Russia. The gap narrowed due to the liberalisation of trading in roubles in China and because of a series of rouble's devaluations in Russia in the period of the end of 2014 and early 2016. So, together with the rouble depreciating against the dollar, the former devalued against the yuan (Jordà, Schularick, Taylor, 2011).

Besides official exchange rates of yuan and rouble, there are contractual exchange rates which appear in currency vehicles at the Moscow Exchange and in the Chinese Foreign Exchange Trading System. These contractual rates are more beneficial to transact in foreign trade. These exchange rates are different from each other. However, the gaps between them are not so large as in the case of the official exchange rates of the nations' central banks discussed above.

According to actual exports and imports data as well as yuan/rouble currency pair trading statistics, among all observations of rouble to yuan exchange rates, the most convenient to use, at least for Russian exporters to China, was swap currency vehicle CNY_TODTOM. It is so because in this contract the rouble was relatively cheaper to buy, and the Russian products would have been more price-competitive if this contract had been used to purchase yuans to cover the bilateral trade deals in the first place. In the reverse situation, for Russia to import from China is more convenient and profitable in the yuan purchased using the currency vehicle in which the rouble is relatively more expensive than the yuan. According to the data collected by the author this would have been currency vehicle CNYRUB_TOD. Choosing this currency vehicle will mean that purchasing the same amount of imported products from China will require fewer roubles. For example, if in 2014 Russia and China transacted wholly in yuan, then buying Chinese goods using currency vehicle CNYRUB_TOD Russian importers would have to pay 240.42 bn yuan, whereas at Bank of Russia exchange rate that would be 241.86bn The difference between these two figures (1.44bn yuan) reflects the amount of money which the Russian importers would not have paid when buying Chinese products in yuan be means of that currency vehicle. However, on the other hand, the Russian exporters would have received 1 bn yuan less if they had traded directly with China in yuan purchased through currency vehicle CNYRUB_TOD in 2014 (Table 4).

If the Russian exporters to China used a spot currency vehicle in the Chinese Foreign Exchange Trading System, the exports value would have amounted to $173.9 \mathrm{bn}$ yuan, which would have also meant losses to the sum of $1 \mathrm{bn}$ yuan. It is 
why the uncertainty which arises when choosing an optimal contract to buy yuan needs a deeper analysis.

To do this, we propose a correlation analysis of actual data beginning in April 2013 showing the exports/imports operations between the BRICS (without China) and China. To reduce the approximation mistake in the gap between the exports/ imports value in yuan at different exchange rates we propose the following conditions:

1) To eliminate external factors which may influence the currencies' exchange rates the author used the method of auto-regression when making a prognosis;

2) Because of a significant devaluation and volatility of the Russian rouble reliable prospective data cannot be obtained because the trend line being applied to the retrospective data has a considerable angle. To this end, the future exchange rate of the rouble to the yuan should be calculated at various stages (Wade, 2008);

3) The future data of the contractual exchange rates of the yuan to the rouble at the Moscow Exchange are adequately verified using adding the yuan-to-rouble exchange rates obtained using the retrospective statistics of the Bank of Russia to their average deviation from the respective contractual exchange rates supplied by the Moscow Exchange;

4) The exports/imports dollar value is forecast using drawing the trend lines to the retrospective data of the exports/imports dollar value taking into account the average square deviation.

On the basis of the correlation analysis of the actual and future data we prove that the influence-factor of the foreign trade volume of the BRICS countries with China depending on the one or the other exchange rate is less significant than the influence-factor of the trading volume in currency pair rouble/yuan at the Moscow and Chinese Exchange and the foreign trade volume of the BRICS with China. For example, the calculations show that in the period of Q3 2013 and Q4 2020 the correlation between the latter is very tight (ranging from 0.7 to 1.0 ) in 20 cases of the 31 observations. In the case of imports and exports of Russia and China, the majority of high correlation figures (21 and 17, respectively) occurs when trading in yuan purchased using currency vehicle CNYRUB_TOM.
The correlation of indicators in question is also proved graphically. For example, it is seen that the dynamics of the actual and prospective data of imports and exports between Russia and China as measured at the rouble-to-yuan exchange rate appearing in spot currency vehicle CNYRUB_TOD and the trading dynamics of this instrument at the Moscow Exchange in the period of 2013-2020 touches the contours and extreme points and coincide in the trend direction, which says of high correlation.

It is worth mentioning that of the eight cases of mutual trade directions within the BRICS only in three of them it is recommended to purchase yuans using spot currency vehicles at the Moscow Exchange (i.e. in case of Russian and Brazilian exports to China and Russian imports from China), whereas in the four of the cases it is better to do it through swap currency vehicles (i.e. Chinese imports to India and South Africa and Indian and South African exports to China). And only in one of the cases (i.e. Brazilian imports from China), it is recommended to use the spot currency vehicle offered by the Chinese Foreign Exchange Trading System (Griesgraber, 2009). In this case, Brazil has more benefits in purchasing yuan, and the high correlation of the exports dynamics and the trading volume of yuan/rouble currency pair is reached there in 20 of the 31 observations. The dominance of swap currency vehicles when purchasing yuan to trade with Brazil, India and South Africa with China can be explained by the fact that they are situated far more distant than Russia, so hedging foreign exchange risks should be done by the former via the longer term contracts (Burlačkov, 2012).

On the whole, the correlation analysis shows that for the BRICS (without China) as trade partners in the foreign trade there are more beneficial conditions to purchase the yuan at the Moscow Exchange than in the Chinese Foreign Exchange Trading System.

Since one of the factors of increasing trading in yuan at the Moscow Exchange is providing a better business environment of buying and selling it compared to other offshore centres, there arises the question about the optimal currency vehicle to purchase yuan. The optimal currency vehicle to buy and sell the yuan, according to the data obtained by the author is the agreement between the exporters and 
importers which is concluded at a more beneficial exchange rate in case of close correlation between yuan's trading volume via a specific currency vehicle and the exports/imports value of the BRICS with China as recalculated into the yuan at a contractual exchange rate of the same currency vehicle.

According to the approach elaborated by the author the exporter/importer of the BRICS when dealing with China, it is recommended to choose the currency vehicle in which there is the maximum number of close correlation observations. And the close correlation between the actual and future forecast indicators of exports/imports and the yuan trading volume at the Moscow Exchange are those situations where the correlation figures lie within 0.7-1.0.

As a result the author comes to the conclusion that for example the Russian exporters and importers to conclude foreign trade deals are recommended to buy yuans via currency vehicle CNYRUB_TOM at the Moscow Exchange, since the close correlation of the imports/exports dynamics as recalculated into the yuan at the exchange rate of that currency instrument is reached in 21 of 31 instances in case of imports and 17 of 31 instances in case of exports.

And only Russian trade partners among the BRICS can buy the yuan for their own national currency. As for Brazil, India and South Africa, their exporters and importers may purchase the yuan only via the system of commercial banks in exchange for the dollars, i.e. when exporting their products to China they will continue to receive in return the dollars. Then they will have to exchange the received dollars into yuan, which they need to do first of all because they usually have a current-account deficit with China. Therefore they require the yuan to cover the existing and future potential debt to pay for the imported Chinese products. And if the conditions to buy the yuan in the Chinese authorised commercial banks and the Chinese Foreign Exchange Trading system are less beneficial, and Brazil, India and South Africa will have to look for better chances to purchase the yuans, they may well buy the roubles for the dollars, and via one of the currency vehicles at the Moscow Exchange they will purchase the yuans for the roubles. So, the more yuan will be received by Brazil, India and South Africa at the Moscow Exchange, the more convenient it is to conclude a foreign trade deal using the latter's currency vehicles.

According to the author's calculations, Brazil could have received the maximum amount of yuan, in 2015 for example, (279.6bn yuan) at the Moscow Exchange in return for the dollars it had got from exporting to China. In the choice of such an alternative, the rouble would be the obligatory intermediary in the foreign exchange deals. It means that the demand for roubles at the Moscow Exchange can rise not only when Brazil, India and South Africa are importing from China, but also when exporting to China. As a result of covering exports/ imports operations of Brazil, India and South Africa in yuan via the Moscow Exchange, the trading volume in currency pair rouble/yuan will increase, which quite certainly will lead to the formation of a yuan offshore centre in Moscow in the long run (Table 5).

To estimate the prospects of yuan's offshore centre can emerge in Moscow, we have developed a prognosis up to 2020 forecasting the changes in the following criteria: the volume of financing exports and imports of the BRICS in yuan and the trading volume in currency pair rouble/yuan at the Moscow Exchange. Then the calculated forecast data are recommended to compare with the corresponding indicators of the existing yuan offshore centre in London. The actual figures of yuan's financing exports/imports operations through London and Moscow Exchange show that they are quite comparable in volume in case of at least 3 per cent import's coverage of the BRICS from China and 2 per cent export's coverage of the former to China.

According to the generated prognosis in order to keep the yuan's trading volumes at the scope of the London offshore centre via the Moscow Exchange using the spot and swap currency vehicles, the yuan should cover at least 5 per cent of the BRICS' imports from China and 3 per cent of their exports to China under the conditions of the Moscow Exchange.

According to the acquired data, the increase in yuan's financing the exports of up to 3 per cent and the imports of up to 5 per cent via the currency vehicles at the Moscow Exchange will be perhaps possible due to the decrease in foreign trade volumes of the BRICS because of a possible diversification of their foreign trade structure 
and due to an increasing number of foreign trade partners (Table 6).

As for comparing the yuan's offshore centreto-be in Moscow and the existing one in London in terms of yuan's trading volumes, the former could have rivalled the latter in case of spot currency vehicle. However, in terms of swap currency vehicle trading volume, Moscow is still lagging behind London. For example, in the first half of 2014, the yuan spot trading deals in London amounted to about $14.5 \mathrm{bn}$ yuan, whereas the swap deals with yuan reached more than 15.6bn yuan. At the same time, the yuan's spot transactions in Moscow totalled 12.2bn yuan, and the swap deals were just 2.4 bn yuan. In the second half of the year, 2014 Moscow outperformed London in terms of yuan's spot trading deals by almost 10bn yuan, whereas the situation with the swap market remained practically unchanged. Significant changes at the Moscow Exchange happened in the second half of 2015 when the volume of spot transactions exceeded 52.7bn yuan, and in the first half of the year 2016 when the swap transactions volume was almost half of London's figure, i.e. 17.6bn yuan.

According to the author's prognosis, yuan's spot trading volumes at the Moscow Exchange are going to increase up to $28.8 \mathrm{bn}$ yuan by the second half of the year 2020. And the figure for the swap transactions will amount to $21.1 \mathrm{bn}$ yuan. On the whole, Moscow may claim for the status of the yuan's offshore centre in terms of growth rates in trading volumes by 2020 (Table 7).

To finish the process of creating an offshore centre of the yuan in Moscow, it is necessary:

1) To have a bigger amount of commercial banks taking deposits expressed in yuan;

2) To increase the number of highly qualified professionals and companies offering complicated financial, legal, insurance, consulting, auditing and credit rating services which generally characterise the normal workings of an international financial centre;

3) To specifically increase the swap trading deals in yuan;

4) To abolish the restrictions on lot limits to buy and sell currency vehicles in case of currency pair rouble/yuan;

5) To assist in yuan's covering exports and imports of the BRICS;
6) To attract debt securities denominated in yuan to circulate in the Russian financial market.

The creation of the yuan's offshore centre in Moscow is, on the one hand, an important step on the path to becoming an international financial centre, and on the other hand, the infrastructure of such a centre largely determines the development of yuan's offshore centre in Moscow.

In turn, the increasing demand for roubles in the Chinese Foreign Exchange Trading System may lead to establishing a rouble's offshore centre in Shanghai, since to increase the amount of liquid assets China will require more roubles which it will be able to purchase either in case of acquiring particular currency vehicles at the Moscow Exchange, or China will want to demand more roubles than dollars in exchange for its imports to Russia.

According to the analysis of different variants to account for the exports/imports operations between China and India, the author proves that both roubles and yuan may well participate in them. When importing from China to India, the rouble may turn the means of exchange in a foreign trade contract under the conditions of direct settlements.

The creation and functioning of a yuan's offshore centre in Moscow will add to the Russian economy the following strong points:

1) Investors in the BRICS will increase the demand for the yuan and the rouble; the same goes for the countries near Russia, for whom China is also one of the most important foreign trade partners;

2) Parallel to increasing demand for yuan and rouble, the latter will strengthen its position as a regional currency for the CIS and the EEU, which will mean a further deepening of the rouble's internationalisation at the macro-level;

3) Active trading in currency vehicles to buy the yuan at the Moscow Exchange will become an important step on the path towards the internationalisation of the rouble itself at the megalevel, and the rouble will gradually convert into an international currency, however, in a very long run.

If Brazil, India and South Africa are to purchase the yuan using the swap and spot currency vehicles at the Moscow Exchange, this operation will be more profitable compared to the conditions of the swap agreements which are bilater- 
ally concluded between the BRICS to cover the mutual trade. Eventually, this will lead to the following results:

1. The yuan's international use is going to expand, i.e. there will be an intensification of its internationalisation at the mega-level. For example, if in 2015 the BRICS' imports and exports were wholly expressed in yuan, its circulating volume abroad would amount to approximately 1.5 trn yuan (or 235.7bn dollars). And although according to the author's prognosis, this figure is going to drop down to 1.2 trillion yuan (or 182.5bn dollars) by 2020, it will not mean a decrease in yuan's use abroad. This reduction, as was said earlier, could be attributed to the increase in the number of China's foreign trade partners and the growth in foreign trade flows with them or the slowdown of the manufacturing capacity of the country itself;

2. Moscow is going to see its status rise to the level of an international financial centre;

3 . The rouble's exchange rate is going to stabilise under a free-floating regime in case of Brazil, India and South Africa are to going to purchase the roubles for dollars (or national currencies), then there will be an increase in the demand for roubles, which will eventually strengthen its positions.

The potential of Moscow as a new yuan's offshore centre and a clearinghouse for the settlements in foreign trade deals of Brazil, India and South Africa, on the one hand, and China, on the other, is proven by the author using an analysis of all exports/imports flows between them, with the exception of Brazilian imports from China, when the conditions of purchasing yuans in the Chinese Foreign Exchange Trading System are more beneficial compared to the Moscow Exchange. The favourable conditions of acquiring yuan at the Moscow Exchange include the diversification of the currency vehicle portfolio using which the buying and selling of yuan are done. Besides, the most optimal contracts to ensure the foreign trade deals of Brazil, India and South Africa with China are the contracts expressed in yuan which have been purchased through swap currency vehicles at the Moscow Exchange, whereas in case of the Russian cross-border transactions that would have to be done by means of spot currency instruments. In case of Moscow becoming an emerging offshore centre of the yuan and by taking advantage of the favourable conditions of the business environment to buy and sell yuan there will be more prerequisites for the rouble's deeper internationalisation.

The creation and effective functioning of the yuan's offshore centre in Moscow is a factor which may intensify the rouble's internationalisation in the long run. For the rouble to go over to the mega level internationalisation may be facilitated by the creation of the rouble's offshore centre in Shanghai by means of increasing trading volumes of roubles using the spot currency pair rouble/yuan vehicle of the Chinese Foreign Exchange Trading System. Increasing rouble's usage via the foreign exchange market in Shanghai can be done using mutually beneficial foreign trade deals between Russia and China in the national currencies. A factor which slows down the growth in rouble trading volumes in Shanghai is an insufficiently diversified and developed export of Russia to China and a tiny share of knowledge-intensive products in their cross-border trade. The establishment and the functioning of a yuan's offshore centre in Moscow may be considered as a transition step to setting up an international financial centre in Moscow.

Russian rouble's internationalisation at the mega level is hypothetically and potentially possible, since it is already being used at several levels of currency internationalisation, i.e. the rouble is a payment currency vehicle, settlement currency vehicle, cross-border transit currency vehicle and deposit currency vehicle at the macro level of currency internationalisation within the EEU; the rouble is a bilateral settlement currency vehicle in cross-border trade with China at the medium level of currency internationalisation; finally, the rouble is a component in currency pair trading rouble/ yuan in the Chinese Foreign Exchange Trading System in Shanghai at the micro level of currency internationalisation. For the rouble to be an international currency the following conditions are accomplished: the rouble is a fully convertible currency, and it fluctuates in term of the free-floating regime. An additional point in favour of rouble's internationalisation at the mega level is a bilateral swap agreement between the central banks of Russia and China. However, the potential for rouble' 
internationalisation at the mega level has decreased due to the economic crisis, devaluation and international sanctions. Still, comparing the corresponding actual and prognosis data of London as an existing yuan's offshore centre and a possible new yuan's offshore centre in Moscow as an emerging market, the author has identified that the latter has certain competitive advantages. And in the long run, under the condition of the increasing use of the roubles and yuan in bilateral trade deals between Russia and China, there will be an increase in the demand for roubles as well as for currency vehicles expressed in roubles and yuan.

Rouble's internationalisation at the mega level as a result of creating a yuan's offshore centre in Moscow may be stimulated by the following factors:

An increase in the demand for roubles on the part of the Chinese Foreign Exchange Trading System as a consequence of a rise in a share of rouble in the volume of rouble-covered exports from Russia to China;

The increase in the demand for the yuan in the Moscow foreign exchange market in case of a rise in bilateral foreign trade transactions between Brazil, Russia, India and South Africa, on the one hand, and Chine, on the other hand. In this situation the rouble is going to become a currency-intermediary in buying/selling swap or spot currency vehicles traded by means currency pair rouble/yuan, so that to purchase the yuan, India, Brazil and South Africa will have to exchange their national currencies or dollars for roubles, and exchange for the received roubles the required yuan. Then in the first instance, Russia will accumulate dollar reserves, and in the second one, there will be an accumulation of the reserves in reals, rupees and rands in Russia, which the country may use for foreign trade settlement deals with the deliverers of the issuing countries.

\section{References}

Avdokušin, Y.F., Kovalenko, V.N. (2012). Perspektivy internatsionalizacii kitaiskogo ûanâ [The prospects of Chinese yuan's internationalisation]. Voprosy novoi ekonomiki, 2, 43-49.

Binder, A.I. (2013). Nekotorye aktual'nie aspekti transformacii ûanâ v mirovuû valûtu [Some acute aspects of transforming yuan into a world currency]. Den'gi i kredit, 11, 59-62.

Burlačkov, V.K. (2012). Reforma mirovoi valûtnoi sistemy i ispol'zovanie èkonomičeskogo invarianta [The reform of the world system of currencies and the use of economic invariant]. Voprosy èkonomiki, 1, 151.

Butorina, O.V. (2011). Valûtnye voiny. Kto zaplatit za preodolenie krizisa? [The currency wars. Who will pay for overcoming the crisis?]. Rossiâ v global'noi politike, 1(9), 165-178.

Goldberg, L.S., Cédric, T. (2008). Vehicle currency use in international trade. Journal of International Economics, 2(76), 177-192.

Griesgraber, J.M. (2009). Reforms for major new roles of the International Monetary Fund? The IMF Post-G-20 summit. Global Governance, 15(2), 179.

Jordà, Ò., Schularick, M., Taylor, A.M. (2011). Financial crises, credit booms, and external imbalances: 140 years of lessons. IMF Economic Review, 59(2), 340-378.

Kadayan, H. (2014). Indian rupee's role as an international currency. Abhinav - National Monthly Refereed Journal In Commerce \& Management, 2(3), 35-43.

Kasekende, L., Brixova, Z., Ndikumana, L. (2010). Africa: Africa’s counter-cyclical policy responses to the crisis. Journal of Globalization and Development, $1,1$.

Kaufman, G.G. (2001). Emerging economies and international financial centers. Review of Pacific Basin Financial Markets and Policies, 4(4), 365-377.

Lane, P.R., Milesi-Ferretti, G.M. (2011). The cross-country incidence of the global crisis. IMF Economic Review, 2011, 59(1), 77-110.

Schindler, M. (2009). Measuring financial integration: A new data set. IMF Staff Papers, 1(56), $222-238$.

Wade, R. (2008). The first world debt crisis of 2007-2010 in global perspective. Challenge, 51(4), 23-54.

Yu, Y. (2014). How far can renminbi internationalization go? Asian Development Bank Institute’s Working Paper, 461, 9-15. 
Table 1

BRICS's share (without Russia) in the Russian foreign trade in 2006-2015, \%

\begin{tabular}{|c|c|c|c|c|c|c|c|c|c|c|}
\hline Indicator & 2006 & 2007 & 2008 & 2009 & 2010 & 2011 & 2012 & 2013 & 2014 & 2015 \\
\hline \multicolumn{11}{|c|}{ Brazil } \\
\hline Exports' share & 0.2 & 0.3 & 0.4 & 0.4 & 0.5 & 0.4 & 0.4 & 0.4 & 0.5 & 0.5 \\
\hline Imports' share & 2.2 & 2.1 & 1.7 & 2.1 & 1.8 & 1.4 & 1.1 & 1.1 & 1.4 & 1.0 \\
\hline \multicolumn{11}{|c|}{ India } \\
\hline Exports' share & 1.0 & 1.1 & 1.1 & 2.0 & 1.6 & 1.2 & 1.4 & 1.3 & 1.3 & 1.5 \\
\hline Imports' share & 0.7 & 0.7 & 0.6 & 0.9 & 0.9 & 0.9 & 1.0 & 1.0 & 1.1 & 1.2 \\
\hline \multicolumn{11}{|c|}{ China } \\
\hline Exports' share & 5.2 & 4.5 & 4.5 & 5.5 & 5.1 & 6.8 & 6.8 & 6.8 & 7.5 & 7.7 \\
\hline Imports' share & 9.4 & 12.2 & 13.0 & 13.7 & 17.0 & 15.8 & 16.3 & 16.8 & 17.7 & 19.3 \\
\hline \multicolumn{11}{|c|}{ South Africa } \\
\hline Exports' share & 0.0 & 0.0 & 0.0 & 0.1 & 0.0 & 0.0 & 0.1 & 0.1 & 0.1 & 0.1 \\
\hline Imports' share & 0.1 & 0.1 & 0.2 & 0.2 & 0.2 & 0.2 & 0.2 & 0.2 & 0.2 & 0.2 \\
\hline
\end{tabular}

Source: compileed by the author.

Table 2

The comparative analysis of the role the rest of the world and the BRICS (without Russia) plays in the Russian foreign trade in 2008-2015

\begin{tabular}{lcccccccc}
\hline \multicolumn{1}{c}{ Indicator } & 2008 & 2009 & 2010 & 2011 & 2012 & 2013 & 2014 & 2015 \\
\hline & \multicolumn{7}{c}{ BRICS (without Russia) } \\
Exports, billion USD & 28.5 & 23.9 & 28.6 & 43.6 & 45.9 & 44.9 & 46.5 & 53.6 \\
Exports share, \% & 6.1 & 7.9 & 7.2 & 8.4 & 8.7 & 8.5 & 9.3 & 9.7 \\
Imports, billion USD & 41.6 & 28.2 & 45.6 & 55.9 & 58.7 & 60.4 & 58.7 & 68.3 \\
Imports share, \% & 15.6 & 16.9 & 19.9 & 18.3 & 18.5 & 19.2 & 20.5 & 20.9 \\
& & & The rest of the world & & & & \\
Exports, billion USD & 439.1 & 277.8 & 368.5 & 473.1 & 478.8 & 481.1 & 451.3 & 503.3 \\
Exports share, \% & 93.9 & 92.1 & 92.8 & 91.6 & 91.3 & 91.5 & 90.7 & 90.2 \\
Imports, billion USD & 225.5 & 139.1 & 183.3 & 249.9 & 258.5 & 254.9 & 228.0 & 264.8 \\
Imports share, \% & 84.4 & 83.1 & 80.1 & 81.7 & 81.5 & 80.8 & 79.5 & 79.0 \\
& & & Total: & & & & & \\
Exports, billion USD & 467.6 & 301.7 & 397.1 & 516.7 & 524.7 & 526.0 & 497.8 & 556.9 \\
Imports, billion USD & 267.1 & 167.3 & 228.9 & 305.8 & 317.3 & 315.3 & 286.7 & 333.1 \\
\hline
\end{tabular}

Source: compiled by the author. 
Table 3

The share of Russia and the rest of the world in the foreign trade of the BRICS (without Russia) in 2008-2015

\begin{tabular}{|c|c|c|c|c|c|c|c|c|}
\hline Indicator & 2008 & 2009 & 2010 & 2011 & 2012 & 2013 & 2014 & 2015 \\
\hline \multicolumn{9}{|c|}{ BRICS (without Russia) } \\
\hline Imports, billion USD & 1698.9 & 1456.6 & 1998.6 & 2554.5 & 2656.2 & 2782.8 & 2754.1 & 3196.8 \\
\hline Exports, billion USD & 1884.6 & 1579.7 & 2081.5 & 2555.9 & 2672.7 & 2860.2 & 2979.2 & 3292.8 \\
\hline $\begin{array}{l}\text { Russia's share } \\
\text { in exports, \% }\end{array}$ & 2.2 & 1.8 & 2.2 & 2.2 & 2.2 & 2.1 & 2.0 & 2.1 \\
\hline $\begin{array}{l}\text { The share of the } \\
\text { Russian produce } \\
\text { in imports, \% }\end{array}$ & 1.7 & 2.1 & 1.5 & 1.8 & 2.0 & 1.9 & 2.1 & 2.0 \\
\hline \multicolumn{9}{|c|}{ The rest of the world } \\
\hline Imports, billion USD & 1669.4 & 1426.7 & 1968.7 & 2507.7 & 2601.9 & 2729.1 & 2696.9 & 3131.6 \\
\hline Exports, billion USD & 1843.0 & 1551.5 & 2035.9 & 2500.0 & 2614.0 & 2799.8 & 2920.5 & 3224.6 \\
\hline $\begin{array}{l}\text { The share of the rest of } \\
\text { the world in imports, \% }\end{array}$ & 98.3 & 97.9 & 98.5 & 98.2 & 98.0 & 98.1 & 97.9 & 97.9 \\
\hline $\begin{array}{l}\text { The share of the rest of } \\
\text { the world in exports, \% }\end{array}$ & 97.8 & 98.2 & 97.8 & 97.8 & 97.8 & 97.9 & 98.0 & 97.9 \\
\hline
\end{tabular}

Source: compiled by the author.

Table 4

Comparative analysis of London and Moscow as yuan's offshore centres in terms of yuan's financing foreign trade transactions in 2012-2016, billion yuan

\begin{tabular}{|c|c|c|c|c|c|c|c|c|c|}
\hline Indicator & $\begin{array}{c}\text { 1st } \\
\text { half of } \\
2012\end{array}$ & $\begin{array}{c}\text { 2nd } \\
\text { half of } \\
2012\end{array}$ & $\begin{array}{c}\text { 1st } \\
\text { half of } \\
2013\end{array}$ & $\begin{array}{l}\text { 2nd } \\
\text { half of } \\
2013\end{array}$ & $\begin{array}{c}\begin{array}{c}1 \text { st } \\
\text { half of } \\
2014\end{array}\end{array}$ & $\begin{array}{c}\text { 2nd } \\
\text { half of } \\
2014\end{array}$ & $\begin{array}{c}\text { 1st } \\
\text { half of } \\
2015\end{array}$ & $\begin{array}{c}\text { 2nd } \\
\text { half of } \\
2015\end{array}$ & $\begin{array}{c}\text { 1st } \\
\text { half of } \\
2016\end{array}$ \\
\hline \multicolumn{10}{|c|}{ London } \\
\hline Import financing & 8.1 & 19.2 & 20.2 & 6.5 & 18.4 & 5.3 & 20.0 & 10.2 & 16.7 \\
\hline Export financing & 2.0 & 4.7 & 4.3 & 7.5 & 7.3 & 2.4 & 4.4 & 8.5 & 7.9 \\
\hline \multicolumn{10}{|c|}{ Moscow } \\
\hline $\begin{array}{l}\text { Conditions } \\
\text { of financing }\end{array}$ & & & & & & & & $5 \%$ & \\
\hline Import financing & 13.3 & 15.3 & 14.0 & 16.3 & 14.2 & 15.5 & 21.3 & 24.5 & 19.9 \\
\hline $\begin{array}{l}\text { Conditions } \\
\text { of financing }\end{array}$ & \multicolumn{6}{|c|}{$2 \%$} & & $3 \%$ & \\
\hline Export financing & 6.6 & 6.3 & 6.5 & 6.6 & 6.7 & 6.6 & 8.2 & 8.9 & 10.7 \\
\hline
\end{tabular}

Source: compiled by the author. 
Table 5

Yuan's financing foreign trade deals through Moscow as a potential offshore centre in 2016-2020, billion yuan

\begin{tabular}{ccc} 
& \multicolumn{2}{c}{ Indicator } \\
\cline { 2 - 3 } Period & $\mathbf{5 \%}$ & Coverage/financing conditions \\
\cline { 2 - 3 } & Import financing & 3\% \\
\hline 2nd half of 2016 & 20.2 & 9.6 \\
1st half of 2017 & 20.7 & 9.8 \\
2nd half of 2017 & 21.7 & 8.8 \\
1st half of 2018 & 18.1 & 7.7 \\
2nd half of 2018 & 19.3 & 7.6 \\
1st half of 2019 & 18.6 & 6.3 \\
\hline 2nd half of 2019 & 17.4 & 6.5 \\
\hline 1st half of 2020 & 19.8 & 5.9 \\
\hline 2nd half of 2020 & 23.1 & 6.6 \\
\hline
\end{tabular}

Source: compiled by the author.

Table 6

The actual yuan trading in London and Moscow in 2012-2016, million yuan

\begin{tabular}{|c|c|c|c|c|}
\hline \multirow{2}{*}{ Period } & \multicolumn{2}{|c|}{ London } & \multicolumn{2}{|c|}{ Moscow } \\
\hline & Spot & Swap & Spot & Swap \\
\hline 1st half of 2012 & 1691.0 & 2468.0 & 756.9 & - \\
\hline 2nd half of 2012 & 2496.0 & 3364.0 & 797.3 & - \\
\hline 1st half of 2013 & 4815.0 & 6260.0 & 1102.2 & 709.3 \\
\hline 2nd half of 2013 & 5564.0 & 7600.0 & 2699.6 & 2256.2 \\
\hline 1st half of 2014 & 14485.0 & 15625.0 & 12242.2 & 2380.5 \\
\hline 2nd half of 2014 & 18350.0 & 18520.0 & 27177.5 & 5710.3 \\
\hline 1st half of 2015 & 24964.0 & 23116.0 & 14944.9 & 5588.5 \\
\hline 2nd half of 2015 & 19297.0 & 28267.0 & 52726.1 & 10251.9 \\
\hline 1st half of 2016 & 36325.0 & 34041.0 & 19785.7 & 17592.9 \\
\hline
\end{tabular}

Source: compiled by the author. 
Table 7

Moscow's performance as a new yuan's offshore centre: the past, the present and the future, million yuan

\begin{tabular}{|c|c|c|c|c|c|c|}
\hline \multirow[b]{2}{*}{ Period } & \multicolumn{3}{|c|}{ Spot market } & \multicolumn{3}{|c|}{ Swap market } \\
\hline & $\begin{array}{c}\text { CNYRUB_ } \\
\text { TOD }\end{array}$ & $\begin{array}{l}\text { CNYRUB_ } \\
\text { TOM }\end{array}$ & Total & $\begin{array}{c}\text { CNY } \\
\text { TODTOM }\end{array}$ & CNY_TOMSPT & Total \\
\hline 1st half of 2016 & 1079.1 & 18706.6 & 19785.7 & 16509.3 & 1083.6 & 17592.9 \\
\hline 2nd half of 2016 & 754.1 & 5163.8 & 5917.9 & 14693.9 & 2325.3 & 17019.3 \\
\hline 1st half of 2017 & 2697.1 & 15183.0 & 17880.1 & 14834.3 & 1636.7 & 16471.0 \\
\hline 2nd half of 2017 & 1460.2 & 14741.4 & 16201.6 & 19024.5 & 1588.9 & 20613.4 \\
\hline 1st half of 2018 & 1100.0 & 12742.5 & 13842.5 & 14991.4 & 3205.2 & 18196.5 \\
\hline 2nd half of 2018 & 2294.5 & 18676.5 & 20971.0 & 13483.5 & 2150.3 & 15633.9 \\
\hline 1st half of 2019 & 1300.1 & 17414.6 & 18714.7 & 19035.7 & 1501.2 & 20537.0 \\
\hline 2nd half of 2019 & 1222.3 & 8108.8 & 9331.2 & 20389.1 & 1739.5 & 22128.6 \\
\hline 1st half of 2020 & 1519.5 & 8954.1 & 10473.6 & 12964.4 & 2175.5 & 15139.9 \\
\hline 2nd half of 2020 & 2324.9 & 24484.4 & 26809.3 & 19694.4 & 1382.3 & 21076.7 \\
\hline
\end{tabular}

Source: compiled by the author.

Москва как новый офшорный центр юаня

Михаил Жариков

Доктор экономических наук, доцент, профессор Департамента мировой экономики и мировых финансов, Финансовый университет, Москва, Россия http://orcid.org/0000-0002-2162-5056

Аннотация. Цель статьи - попытка обосновать и доказать перспективы Москвы как нового офшорного центра юаня. Изучив деятельность Московской биржи, где имеется функционирующая ниша для осуществления валютных торгов по валютной паре рубль/юань, а также коммерческих банков, которые принимают депозиты, выраженные в юанях, от физических и юридических лиц, автор предлагает использовать данное преимущество в целях создания особо благоприятного инвестиционного климата для Бразилии, Индии и ЮАР в рамках ведения торгов по валютной паре рубль/юань на Московской бирже в случае организации прямых импортно-экспортных сделок между ними и Китаем.

Ключевые слова: страны БРИКС; интернационализация рубля; офшорный центр юаня в Москве; международная валютная система; Евразийский экономический союз; евразийская валютная интеграция; юаневые валютные инструменты; контрактные обменные курсы юаня 